\title{
PEMBENTUKAN KaBUpATEN LUWU UTARAs KISAH DARI TOKOH DI BALIK LAYAR PADA 1999
}

\author{
THE FORMATION OF THE NORTH LUWU DISTRICT: \\ THE STORY OF THE ACTORS BEHIND THE SCENE IN 1999
}

\author{
Rismawidiawati \\ Balai Pelestarian Nilai Budaya Sulawesi Selatan \\ Jalan Sultan Alauddin km.7 Makassar, Provinsi Sulawesi Selatan, Indonesia \\ e-mail: rismawidiawati@gmail.com

\begin{abstract}
Abstrak
Artikel ini bertujuan untuk menulis sejarah pembentukan Kabupaten Luwu Utara dari perspektif aktor yang terlibat pada proses pembentukan tersebut. Tulisan ini menggunakan metode sejarah, dan hasil penelitian menunjukkan bahwa upaya pembentukan Kabupaten Luwu Utara bukan hanya sekali ini muncul, tapi keinginan tersebut sudah sejak lama diperjuangkan. Usaha tersebut dimulai sejak 1959, diulang kembali pada 1966, dan akhirnya pada 1999 Kabupaten Luwu Utara terbentuk. Pembentukan Luwu Utara adalah berkat perjuangan masyarakat Luwu Utara yang terdiri dari berbagai unsur, unsur mahasiswa yang tergabung pada Forum Komunikasi Mahasiswa Luwu Utara, unsur masyarakat biasa bahkan unsur pemerintah. Cepatnya proses pembentukan Luwu Utara pada 1999 ini berkat politik lobbying yang dilakukan oleh Ryass Rasyid yang memiliki kedekatan khusus dengan Lutfi A. Mutty (Dirjen PUOD). Alasan Utama pembentukan Kabupaten Luwu Utara tidak hanya dikarenakan pertimbangan desentralisasi, demokratisasi dan good governance, serta kalkulasi ekonomis namun juga karena kepentingan aktor-aktor dibaliknya.
\end{abstract}

Kata kunci: Luwu Utara, Masamba, lobi politik.

\begin{abstract}
The study aims to reveal the history of the formation of the North Luwu District based on the perspective of the actors who were directly involved in the formation process. This research, which uses the historical method, shows the results of the research that the efforts to form the North Luwu District have been pursued for a long time. The effort, which had been started since 1959, was re-submitted in 1966, and finally in 1999 the North Luwu District was successfully formed. The formation of North Luwu District was the result of support from the North Luwu communities which consisted of various elements, such as elements of students who were members of the North Luwu Student Communication Forum, elements of societies, and even elements of the government. The process of formation the North Luwu District in 1999 proceeded rapidly because of political lobbying approached by Ryass Rasyid towards Director General for PUOD Lutfi A. Mutty. The main reasons behind the formation of the North Luwu District was not only due to the considerations of decentralization, the democratization and the good governance, as well as the economic calculations but also because of the interests of the actors behind it.
\end{abstract}

Keywords: Luwu Utara, Masamba, political lobbying.

\section{A. PENDAHULUAN}

Tidak dapat disangkal bahwa otonomi daerah yang bergulir di Indonesia, memberikan wacana beragam yang membuat beberapa daerah ingin pula memekarkan diri. Tampaknya terdapat harapan besar dalam masyarakat daerah ketika membentuk provinsi ataupun kabupaten baru akan dapat meningkatkan kesejahteraan mereka. Harapan besar ini 
juga tercermin dalam semangat masyarakat Masamba ketika memperjuangkan pembentukan Luwu Utara.

Namun demikian, pada kenyataannya setelah 19 tahun berlalu sejak Kabupaten Luwu Utara memisahkan diri dari Kabupaten Luwu, masih terdapat banyak infrastruktur yang belum terbenahi bahkan jauh dari kata layak di Luwu Utara ketika penelitian ini dilakukan pada tahun 2018. Padahal salah satu alasan klasik sehingga Masamba ingin lepas dari Luwu di masa itu karena tidak meratanya pembangunan di Masamba dan sekitarnya yang sekarang masuk dalam wilayah Luwu Utara.

Kenyataan di atas memperlihatkan terdapat jarak yang timpang antara dalih atau alasan pembentukan Luwu Utara dan kenyataan yang sebenarnya. Pemekaran daerah mengandung masalah kompleks, tidak hanya terkait dengan pemerataan pembangunan dan peningkatan kesejahteraan, tetapi juga tidak dapat dilepaskan dari kepentingan politik aktor yang berperan terhadap pemekaran/ pembentukan tersebut.

Studi tentang politik lokal pasca reformasi telah mendapat perhatian dari berbagai ilmuwan dengan beragam perspektif. Syarif Hidayat, Erwiza Erman, dan Agus Syarip Hidayat, secara konsisten melihat aktor-aktor lokal dalam melihat relasi kekuasaaan dan pebisnis dalam pemerintahan di tingkat lokal. Studi-studi lain yang diprakarsai oleh KITLV, yang selama dua tahun mengerahkan sebuah kelompok internasional yang terdiri atas 24 peneliti terutama dari Indonesia dan Belanda, dan juga Amerika Serikat, Australia, Jerman, Kanada, dan Portugal. Penelitian ini meletakkan desentralisasi dan berkurangnya kekuasan negara dan ruang yang lebih bebas bagi perdagangan dan demokrasi. Di berbagai daerah, penelitian ini mengungkap dinamika politik lokal di Indonesia (Nordholt dan Klinken, 2007).

Pembentukan daerah otonom pada dasarnya implikasi dari perkembangan desentralisasi pemerintahan. Argumentasi teoritis yang dikemukakan oleh Arghiros bahwa desentralisasi didudukkan sebagai alat (mean) dan demokratisasi di tingkat lokal diartikulasi sebagai tujuan (goal). Melalui kebijakan desentralisasi, dapat dikurangi sentralisasi kekuasaan ditangan pemerintah pusat (Arghiros, 2001). Kepentingan aktor-aktor politik dibalik terbentuknya Kabupaten Luwu Utara tidak terlepas dari implikasi perubahan paradigma pemerintahan dari sentralisasi ke desentralisasi.

Berkaca pada beberapa tulisan sebelumnya sebut saja tulisan M. Thamrin Mattulada tentang Dinamika Politik Pembentukan Provinsi Sulawesi Barat. Karya ini memperlihatkan dinamika lokal pembentukan Sulawesi Barat (Mattulada, 2017). Kemudian karya Basri Amin dkk (Amin, Hasanuddn dan Tilome, 2013) secara konprehensif menggambarkan proses pembentukan Provinsi Gorontalo. Baik karya M. Thamrin Mattulada maupun karya Basri Amin, keduanya menguraikan kompleksitas proses pemekaran wilayah.

Tulisan lain yang secara gamblang menyebutkan adanya kepentingan pada pembentukan suatu daerah sampai terjadi konflik adalah tulisan yang berjudul Elit dan Pemekaran Daerah; Konflik Antar Elit dalam Proses Pembentukan Provinsi Banten (Rohmah, 2018). Selain itu, tulisan tentang analisis peran aktor dalam pemekaran Kabupaten Brebes juga menyebutkan adanya kepentingan yang begitu jelas dibahas (Trisnawati, 2015).

Tentu masih banyak tulisan-tulisan tentang pembentukan provinsi/kabupaten yang terang-terangan mengungkap adanya aktor yang memiliki kepentingan dibalik pembentukan daerah. Apakah pembentukan Luwu Utara juga demikian? Tentu hal ini juga menjadi fokus perhatian pada tulisan ini. Walaupun telah banyak tulisan tentang pemekaran atau pembentukan sebuah daerah namun setiap daerah tentu saja memiliki alasannya masing-masing.

Secara khusus karya Asdar Muis RMS tentang Luthfy A. Mufti: Pioneer 
Luwu Utara, mengantar penulis untuk menggali lebih jauh dan menjawab persoalan artikel ini. Karya Luthfy ini merupakan pandangan dari seorang tokoh politik Luwu Utara dan memiliki peranan penting dalam proses pembentukan Luwu Utara. Kendatipun dapat dilihat sebagai pandangan subjektif, tetapi karya ini memberi informasi sangat penting dalam melihat aktor dibalik terbentuknya Kabupaten Luwu Utara.

Ungkapan history is always written by the winner tepat kiranya disematkan pada karya di atas. Karya Muis ini menyebutkan bahwa Luthfi sebagai pionir pembentukan daerah tanpa menyebutkan orang lain yang terlibat. Walaupun demikian, karya ini menjadi pijakan awal penulis ketika mencari data di lapangan.

Berpijak pada hal itu, maka tulisan ini ingin melihat dan bercerita dari sisi berbeda yaitu menjelaskan proses pembentukan Kabupaten Luwu Utara dari penuturan aktor-aktor lain yang turut berperan. Walaupun demikian, tulisan ini tentunya tidak mengabaikan peran Lutfi sebagaimana yang diuraikannya di dalam bukunya tersebut (Muis, 2008).

Seperti layaknya proses pemekaran di berbagai daerah di Indonesia, di Masamba pun klaim terhadap pengaruh tokoh tertentu di balik terbentuknya Luwu Utara juga bermunculan. Disinilah persoalan penting penelitian ini, yaitu ingin mengurai proses terbentuknya Luwu Utara. Proses terbentuknya Luwu Utara disini dengan menjelaskan tokoh-tokoh yang ada dibalik pembentukan dan mengurai kepentingankepentingan yang ada dibalik pembentukan.

Penelitian ini penting untuk dilakukan karena menulis tentang sejarah daerah tertentu adalah upaya membangun kesadaran sejarah generasi muda. Diharapkan dengan adanya pengetahuan tentang sejarah daerah membuat generasi muda terbuka mata dan hatinya untuk lebih mencintai daerahnya. Selain itu, ungkapan bahwa jika sejarah tidak ditulis akan menjadi dongeng turut memberi nilai tambah tentang pentingnya tulisan ini.

Demikian pula, masih minimnya karya historigrafi daerah sehingga literasi kesejarahan masih terbatas menambah pentingnya penulisan artikel ini. Hal ini berdasarkan pengalaman peneliti selama menjadi peneliti dimana ketika harus mencari data pada skop waktu tertentu, itu akan sulit ditemukan.

Padahal di era otonomi daerah saat ini, informasi tentang sejarah daerah tertentu sangat diperlukan ketika ingin mengambil kebijakan-kebijakan tertentu. Pengetahuan tentang sejarah daerah tidak bisa dinafikan betapa pentingnya posisinya. Seperti pernyataan Soekarno yang mengatakan "jangan sekali-kali melupakan sejarah". Pernyataan ini bukan merupakan tong kosong yang tak memiliki makna. Di dalam sejarah kita dapat belajar bagaimana mengatur masa kini dan masa yang akan datang.

Kesadaran sejarah yang ditunjang oleh pengetahuan masa lampau dalam hal ini tentang pembentukan Kabupaten Luwu Utara yang obyektif akan menimbulkan empati generasi muda terhadap daerahnya dengan cara 'relive' dan 'rethink' terhadap tindakan-tindakan pada masa lampau (Hughes, 1964: 1-21). Untuk selanjutnya, empati ini akan membangkitkan keingintahuan untuk menggali lebih dalam perjalanan daerah di masa lampau dalam rangka untuk menemukan jawaban dari mengapa segala sesuatu menjadi seperti apa yang terlihat pada masa kini.

Berdasarkan argumentasi di atas, maka penelitian tentang sejarah terbentuknya Kabupaten Luwu Utara penting dilakukan untuk mencegah ammesia historis di kalangan generasi muda. Generasi muda yang memiliki kesadaran sejarah akan mencari jawabannya dengan belajar sejarah, dan setelah itu ia akan menjadi lebih arif dan bisa memberikan sumbangan pemikiran. Upaya menulis sejarah Kabupaten Luwu Utara bertujuan untuk membangun ingatan masa lalu sebagai suatu kekuatan untuk 
pemikiran kekinian. Mengingat adalah sebuah tindakan imaginatif, sebuah proses konstruktif yang kreatif. Sebab yang diingat adalah yang dipahami, yang dimengerti, dan yang dipahami atau yang dimengerti itu adalah yang diperhatikan, dan yang diperhatikan adalah sesuatu yang kita inginkan (Erman, 2012: 101). Semua proses mengingat masa lalu adalah produk dari kesadaran individu, masyarakat, dan bahkan negara. Menulis sejarah Kabupaten Luwu Utara adalah upaya mengingat untuk menciptakan colective memory sebagai landasan untuk membangun karakter dan jadi diri bangsa.

Terkait dengan latar di atas, maka rumusan masalah tulisan ini adalah:

1. Mengapa Luwu dimekarkan dengan membentuk Kabupaten Luwu Utara?

2. Bagaimana proses pembentukan Kabupaten Luwu Utara?

3. Siapa sajakah aktor di balik layar yang membantu pembentukan Kabupaten Luwu Utara?

\section{B. METODE PENELITIAN}

Penelitian ini menggunakan metode sejarah melalui tahapan heuristik, kritik, interpretasi dan historiografi. Tahap heuristik dilakukan dengan dua cara, yaitu dengan penelitian lapangan dan studi pustaka.

Penelitian Lapangan (field research) dimaksudkan bahwa penulis langsung melakukan penelitian pada lokasi untuk mendapatkan sumber lisan. Penelitian lapangan ditempuh dengan cara sebagai berikut:

- Observasi yaitu pengamatan terhadap objek secara langsung, dengan tinggal di daerah penelitian selama 15 (lima belas) hari.

- Interview yaitu wawancara langsung dengan informan yang telah ditentukan dalam hal ini yang terlibat langsung pada pembentukan Luwu Utara 1999. Beberapa kali juga ketika tulisan ini sedang dirakit, penulis melakukan kontak wawancara melalui sambungan telepon dengan beberapa informan terkait data yang harus dilengkapi.

Focus Group Discussion dengan tokoh-tokoh yang berpengaruh. Informan dikumpulkan pada Diskusi terpimpin (FGD) dan ada juga yang diwawancarai langsung di kediamannya. Informan terdiri atas mantan camat pada masa pemekaran serta tokoh-tokoh masyarakat. Tak lupa juga turut hadir mahasiswa yang ikut terlibat ketika pembentukan Kabupaten Luwu Utara tersebut.

Pengumpulan data dilakukan juga dengan cara membaca literatur-literatur yang berhubungan dengan proses pembentukan Luwu Utara seperti koran, buku, dokumen pembentukan daerah baik berupa laporan, peraturan dan surat-surat keputusan. Peneliti menelusuri perpustakaan yang ada di Makassar maupun yang ada di Masamba sebagai lokus penelitian. Peneliti juga mendapatkan data dari buku-buku dan arsip-arsip milik para narasumber di Masamba.

Tahap kritik dilakukan dengan membandingkan data yang diperoleh antara satu narasumber dengan narasumber yang lain, selain itu juga membandingkan dengan laporan yang ada pada masa pembentukan. Selanjutnya data diinterpretasi dan dirakit menjadi sebuah tulisan yang utuh tentang pembentukan Kabupaten Luwu Utara.

\section{HASIL DAN BAHASAN}

Gagasan pembentukan Kabupaten Luwu Utara bukanlah hal yang baru, tetapi merupakan ide yang telah lama diperjuangkan oleh para tokoh dan pejuang pembentukan Kabupaten Luwu Utara. Ada banyak pihak atau orang yang pasti ingin menjadi bagian dari pembentukan wilayah ini dan ingin diakui akan hal itu. Tapi bagaimanakah dan sejauh apakah peran masing-masing pihak terhadap pembentukan Luwu Utara?

Para aktor yang terlibat dalam proses pembentukan Luwu Utara dapat 
dikatakan sebagai agency karena memiliki kemampuan memahami lingkungan sosial, politik, budaya dan kapasitas untuk melakukan perubahan. Dalam pandangan Christopher Lloyd (Lloyd, 1993: 97) bahwa kemampuan untuk memahami diri mereka sendiri kemudian disebut mentality. Artinya, bagaimana agency mengekspresikan diri mereka melalui agama, ritus, busana, musik dan lain sebagainya. Oleh karena itu, gagasan pembentukan Luwu Utara dapat dikatakan sebagai product of mentality.

Penelitian ini berusaha mengkonseptualisasi Luwu Utara dengan mengkaji proses pembentukan struktur dengan memeriksa interaksi sebab akibat dari para tokoh/aktor, kelompokkelompok, kelas-kelas dan pengstrukturan kondisi-kondisi sosial, keyakinankeyakinan dan keinginan-keinginan aktor, kelompok atau kelas-kelas tersebut, sehingga Luwu Utara tergambar seperti apa yang kita saksikan sekarang ini sebagai sebuah proses dialektika yang panjang.

\section{Dasar Pemikiran Pemekaran Luwu 1999}

Pemekaran Luwu pada 1999 tidak serta merta dilakukan karena alasan ingin membangun masyarakat yang lebih sejahtera, demokratis dan berorientasi pada pembangunan. Alasan tersebut adalah alasan yang memang harus dimiliki oleh sebuah daerah yang akan dibentuk. Alasan dibalik terbentuknya Kabupaten Luwu Utara tidak hanya dikarenakan pertimbangan desentralisasi, demokratisasi dan good governance, serta kalkulasi ekonomis namun juga karena kepentingan aktor-aktor dibaliknya.

Terbentuknya Kabupaten Luwu pada 1999 tidak dapat dilepaskan dari kepentingan aktor-aktor yang mengupayakan pemekaran itu sendiri. Dari pengantar yang disampaikan oleh Ryass Rasyid pada buku Lutfi A. Mutty: Pionir Luwu Utara diketahui bahwa triggernya adalah tidak terpilihnya Lutfi A. Mutty menjadi Bupati Luwu periode 1999 - 2004
(Muis, 2008: xxvii). Ryass Rasyid yang memiliki kedekatan khusus dengan Lutfi dan sekaligus pada saat itu sedang menjabat sebagai Dirjen PUOD (Pemerintahan Umum dan Otonomi Daerah) memanfaatkan kesempatan yang ada. Rupanya kedekatan tersebut menjadi faktor penting terhadap terbentuknya Kabupaten Luwu Utara kemudian (Nordholt dan Klinken, 2007: 179).

Bersamaan dengan maraknya gerakan pemekaran daerah, Ryass Rasyid lalu mengusulkan pemekaran Luwu sebagai obat pelipur lara bagi Lutfi. Walaupun Lutfi sendiri mengaku tidak kecewa atas tidak terpilihnya sebagai Bupati Luwu, namun tampaknya ide Ryass Rasyid ini dilakukan untuk memberi ruang kepada Lutfi A. Mutty.

Alasan lain yang tidak dapat diabaikan bahwa perjuangan pemekaran wilayah di Luwu menyimpan sejumlah pertanyaan besar dan sebuah agenda tersembunyi untuk pembentukan Provinsi Luwu Raya yang ketika itu sedang marak diperbincangkan di tingkat nasional. Agenda-agenda ini juga menjadi jalan yang mempermulus pembentukan Luwu Utara disamping peran berbagai aktor di dalamnya. Semua faktor tidak dapat diabaikan dalam proses terbentuknya Luwu Utara (Nordholt dan Klinken, 2007: 162-163).

Peluang untuk mengubah struktur dan bentuk pemerintahan lokal yang terjadi sejak UU Nomor 22/1999 diberlakukan, mengakibatkan Provinsi Sulawesi Selatan kebanjiran tuntutan pembentukan provinsi baru dan kabupaten baru. Dalam suasana penguatan daerah lokal, wilayah itu terancam pemisahan menjadi sampai lima provinsi dalam batasan wilayah propinsi induk. Sebagai dirjen PUOD kala itu, tentunya tuntutan semacam ini akan singgah di meja Ryass Rasyid. Berdasarkan pertimbangan tersebut, Ryass Rasyid lalu mengusulkan kepada Gubernur Sulawesi Selatan HZB Palaguna untuk menyetujui pemekaran Luwu sebagai 
antisipasi sebelum gerakan serupa terjadi (Muis, 2008: xxvii).

Salah satu faktor krusial penentu keberhasilan pengelolaan manajemen pemerintahan adalah sejauh mana kedekatan dan kecepatan pelayanan pemerintahan yang diberikan kepada masyarakat. Berbicara perihal kedekatan dan kecepatan pelayanan pemerintahan akan mengarahkan kita pada dua aspek pokok yaitu pertama, letak geografis titik pusat layanan pemerintahan dan kedua, ketersediaan prasarana dan prasarana pusat layanan pemerintahan (Agung, 2016: 1-8).

Dalam hubungannya dengan pemekaran suatu wilayah pemerintahan baik itu provinsi maupun kabupaten tentunya faktor pertama yang diajukan sebagai proposal adalah peningkatan pemberian pelayanan prima pemerintahan kepada masyarakat dan ini sangat erat terkait dengan pertimbangan kedekatan dan ketepatan pemberian pelayanan pemerintahan. Logika sederhana menegaskan bahwa semakin jauh jarak geografis masyarakat dengan pusat pelayanan pemerintahan maka akan semakin lambat masyarakat memperoleh layanan publik yang dibutuhkan dan semakin besar biaya finansial yang dibutuhkan untuk memperoleh layanan yang dibutuhkan.

Semakin luas suatu wilayah geografis pemerintahan akan semakin menyulitkan pembinaan, pengawasan dan pengendalian pemerintahan disebabkan oleh rentang kendali yang semakin melebar, apalagi jika kondisi tersebut diperburuk oleh keterbatasan SDM aparat pemerintahan serta minimalnya pendelegasian kewenangan kepada aparat pemerintahan pada level terdepan dalam struktur pemerintahan yang notabene langsung berhadapan dengan masyarakat yang perlu dilayani.

Bertolak dari pemikiran tersebut di atas, maka timbullah aspirasi untuk memekarkan wilayah administratif pemerintahan Kabupaten Luwu menjadi dua kabupaten yaitu Kabupaten Luwu (induk) dan Kabupaten Luwu Utara (pemekaran). Luas administratif Pemerintahan Luwu pada 1999 adalah $17.791,43 \mathrm{~km}^{2}$.

Luas wilayah Kabupaten Luwu ini masih lebih luas daripada penggabungan keseluruhan 12 kabupaten dan kota yaitu Kota Makassar $\left(177,77 \mathrm{Km}^{2}\right)$, Kabupaten Maros $\quad\left(1.619,12 \quad \mathrm{Km}^{2}\right), \quad$ Kabupaten Pangkep (1.112,29 Km²), Kabupaten Barru $\left(1.174,71 \mathrm{Km}^{2}\right)$, Kota Pare-Pare $(99,33$ $\left.\mathrm{Km}^{2}\right)$, Kabupaten Sidrap $\left(1.883,25 \mathrm{Km}^{2}\right)$, Kabupaten Gowa $\left(1.883,32 \mathrm{Km}^{2}\right)$, Kabupaten Takalar (566,51 $\left.\mathrm{Km}^{2}\right)$, Kabupaten Jeneponto (737,64 $\left.\mathrm{Km}^{2}\right)$, Kabupaten Bantaeng (395,83 $\left.\mathrm{Km}^{2}\right)$, Kabupaten Bulukumba $\left(1.154,67 \mathrm{Km}^{2}\right)$, dan Kabupaten Sinjai $\left(819,96 \mathrm{Km}^{2}\right)$, yang luas penggabungan seluruhnya adalah $11.624,40 \mathrm{Km}^{2}$. Sedangkan luas Provinsi Sulawesi Selatan sendiri adalah 62.482,51 $\mathrm{km}^{2}$, ini berarti bahwa Kabupaten Luwu waktu itu memiliki hampir sepertiga luas wilayah Provinsi Sulawesi Selatan.

Secara umum letak geografis calon Kabupaten Luwu Utara (sebelum terbentuknya Kabupaten Luwu Timur) berada pada ujung paling timur daripada Provinsi Sulawesi Selatan yang langsung berbatasan dengan 2 (dua) provinsi yaitu Provinsi Sulawesi Tengah dan Provinsi Sulawesi Tenggara. Keuntungan yang didapat dengan adanya letak strategis pada perbatasan kedua provinsi tersebut adalah dapat menstimulir peningkatan aktivitas perdagangan antar provinsi yang pada gilirannya akan meningkatkan pendapatan masyarakat dan memacu peningkatan pembangunan sarana dan prasarana pendukung yang dibutuhkan. Salah satu dukungan geografis yang sangat bersifat strategis bagi daerah atau wilayah yang ingin cepat berkembang adalah keuntungan dengan adanya garis pantai yang dapat dikembangkan sebagai sarana pendukung bagi perkembangan sektor perikanan dan transportasi laut dalam rangka percepatan arus manusia, barang dan jasa.

Jadi, alasan pemekaran Kabupaten Luwu Utara menjadi dua kabupaten yaitu 
Kabupaten Luwu (induk) dan Kabupaten Luwu Utara (pemekaran) bukan saja dilandasi oleh semangat emosional atas eforia reformasi, akan tetapi juga dilandasi oleh kebutuhan masyarakat akan pelayanan pemerintahan yang cepat dan prima serta landasan logika pemerintahan yaitu sulitnya rentang kendali pemerintahan yang disebabkan oleh terlalu luasnya wilayah administratif pemerintahan, dan kondisi ini akan berimbas pada lambat dan mahalnya pelayanan publik yang diberikan kepada masyarakat, utamanya masyarakat yang jauh dari ibukota pemerintahan (Yosephus, 2014: 1-10) .

Motivasi untuk memekarkan diri timbul dari perasaan terabaikan oleh pemerintah provinsi yang terletak ratusan kilometer ke arah selatan di Kota Makassar. Dengan menuntut pemerintahan yang akan lebih memahami dan memperhatikan persoalan dan keadaan lokal, penduduk di daerah Luwu Raya ini melawan sentralisasi yang terjadi di tingkat provinsi. Di Sulawesi Selatan sejak era perjuangan kemerdekaan penduduk sering mendesak desentralisasi atau melawan sifat dan perbuatan sentralisme di tingkat nasional.

Pada tahun 1947 Kota Makassar menjadi ibu kota federasi Negara Indonesia Timur, namun kehilangan posisi ini ketika NIT itu dibubarkan. Kemudian, perasaan ketidakadilan dan ketidakpuasan terhadap struktur pemerintahan Republik Indonesia pada tahun 1957 mengakibatkan salah satu faktor penyebab perang Darul Islam yang dipimpin Kahar Muzakkar. Menurut analisis Barbara Harvey, perang ini muncul dari penolakan para pejuang Sulawesi Selatan yang tidak diangkat oleh pemerintah pusat sebagai pejabat dan pemimpin militer (Harvey, 1983: 430 435). Pendukungan B.J. Habibie pada waktu Pemilu 1999 bisa juga dianggap tindakan anti-sentralisme. Demikian pula perasaan kekecewaan yang muncul dengan protes Sulawesi Merdeka setelah penolakan Laporan Pertanggungjawaban Habibie pada bulan Oktober 1999.
Landasan pemikiran yang diuraikan diatas kemudian dituangkan dalam undang-undang Republik Indonesia Nomor 13 Tahun 1999 tentang Pembentukan Kabupaten Daerah Tingkat II Luwu Utara.

\section{Politik-Keamanan dan Gagalnya Pembentukan Kabupaten Luwu Utara}

Wilayah eks Onder-afdeling Masamba atau Kewedanan Masamba, terbentang dari Kecamatan Masamba di sebelah barat hingga Kecamatan Towuti di sebelah timur, membujur dari Kecamatan Mangkutana di sebelah utara hingga Kecamatan Malili di sebelah selatan. Pembentukan daerah ini menjadi kabupaten melalui perjalanan panjang, suka dan duka bagi para penggagas dan penginisiatif yang akan menjadi kenangan yang tak akan terlupakan sepanjang masa. Untuk menelaah proses perjuangan tersebut, perlu pula melihat situasi politik, keamanan dan iklim pemerintahan dalam sejarah Luwu Utara sebagai bagian integral dari sejarah terbentuknya Luwu Utara.

Gagasan pembentukan Kabupaten Luwu Utara mulai merebak dan diperjuangkan secara bersungguh-sungguh sejak tahun 1959. Sebagai dasar utamanya, secara sangat jelas termaktub dalam Undang-undang Nomor 29 Tahun 1959 tentang Pembentukan Daerah Tingkat II di Sulawesi Selatan (L.N. 1959 Nomor 74 TLN Nomor 1822) yang mengamanatkan bahwa semua Daerah Eks Onder Afdeling di Sulawesi Selatan, termasuk di antaranya bekas Kewedanan Masamba akan ditingkatkan statusnya menjadi kabupaten. Akan tetapi, usaha pembentukan Kabupaten Luwu Utara gagal karena situasi keamanan Sulawesi Selatan, terutama adanya Gerakan DI/TII Kahar Muzakkar, di mana ruang lingkup gerakan ini juga meliputi wilayah Kewedanan Masamba.

Pada periode tersebut situasi ketentraman dan keamanan pada hampir seluruh kawasan ini, sangat mencekam dan memprihatinkan akibat aksi para 
gerombolan pemberontak yang membumihanguskan banyak tempat, termasuk Kota Masamba. Peristiwa ini, secara langsung melahirkan semangat heroisme yang membara, khususnya di kalangan para pemuda pada waktu itu, untuk berjuang keras dengan tujuan membangun kembali wilayah eks Kewedanan Masamba yang porak poranda.

Keadaan politik yang destruktif dapat ditelusuri sejak periode 1950an, dimana kehidupan politik ditandai dengan munculnya sistem pemerintahan koalisi partai politik. Partai politik merupakan institusi yang mengakomodasi sekaligus mengartikulasi aspirasi masyarakat, sehingga tentunya partai politik itu akan masuk dalam jajaran elit pemerintahan. Partai politik akan memberikan peran dalam perjuangan politik, karena itu eksistensinya tidak bisa terbantahkan lagi. Masa dominasi partai politik ini dalam sejarah Indonesia dikenal sebagai masa demokrasi parlementer.

Pertarungan politik di pusat melahirkan pengelompokan politik di daerah. Pengelompokan ekonomi dan budaya yang saling memotong di tingkat lokal menjadi tumpang tindih dengan afiliasi politik (Sulistyo, 2000: 132). Bandingkan dengan kasus di Jawa Timur. Konfrontasi budaya yang terjadi seperti adanya upaya menggeser peran-peran elit yang secara kultural sudah pengakar dalam kepemilikan tanah dan ambruknya ekonomi petani, dimasuki berbagai organisasi massa yang merupakan afiliasi dari partai-partai yang masih bertarung di tingkat pusat. Daerahlah yang merasakan akibat terburuknya.

Hasilnya bukan politik aliran di tingkat elit, tetapi juga pada basis massa di mana masyarakat terpilah secara vertikal dan horizontal dalam aliran-aliran politik dan partai, yang dikelilingi sejumlah organisasi sosial yang terkait dengannya, baik secara formal maupun non formal (Sulistyo, 2000: 132). Organisasiorganisasi massa bergerak sesuai dengan garis politik partai yang mendukungnya.
Pertarungan di tingkat elit berlanjut di massa dimana segmen masyarakat sipil terbanyak berada di lapisan ini. Fenomena ini terjadi di Sulawesi Selatan dengan ciri khas maraknya partai politik dan suburnya organisasi sosial masyarakat yang berhaluan politik-ideologis. Dalam konteks demokrasi, tentunya hal ini sangat baik untuk pertumbuhan dinamika politik, tetapi sangat destruktif untuk negara yang baru saja merdeka.

Partai-partai politik masing-masing membentuk organisasi massa sebagai alat propaganda untuk mencari dan merebut hati masyarakat. Salah satu contoh aliranaliran politik itu telah memperluas pengaruhnya di kalangan massa organisasi buruh. Serikat Buruh Indonesia (SBI) dari Masyumi, Himpungan Buruh Indonesia (HIMBI) dari PNI, sedang Partai Sosialis Indonesia (PSI) terutama melebarkan pengaruhnya pada organisasi-organisasi buruh yang tergabung dalam Badan Perjuangan Buruh, Partai Buruh pada organisasi Gabungan Organisasi Buruh Indonesia (GOBI), dan PKI pada organisasi-organisasi Anggota Sentral Organisasi Buruh Seluruh Indonesia (SOBSI) Kondisi ini kemudian menimbulkan gesekan-gesekan di tengahtengah masyarakat yang sifatnya sporadis dan prontal. Setelah pemilu dilaksanakan konflik yang semakin tajam justru sekitar tahun 1960-an. Setiap partai yang terlibat dalam pertarungan mulai mengambil posisi terbuka dan keras. Gelombang aksi buruh semakin marak dilakukan dengan tujuan untuk meningkatkan kesejahteraan mereka, tercatat dari tahun 1952 sampai tahun 1960-an sekitar 4172 aksi pemogokan buruh di Sulawesi Selatan. Masalah yang menjadi tuntutan mereka adalah, kenaikan upah, pemberhentian, hadiah lebaran, dan jaminan kesehatan (Kementerian Penerangan, 1952: 518-519).

Pengelompokkan politik tidak hanya di kalangan buruh, tetapi juga di kalangan pelajar, mahasiswa, dan organisasi profesi. Masing-masing partai seakan berlombalomba mendirikan organisasi massa di 
semua lapisan masyarakat. Akibatnya masyarakat terpecah dalam berbagai aliran politik dengan ideologi dan garis perjuangan yang berbeda-beda (Kementerian Penerangan, 1952: 519).

Pengelompokkan politik dan ideologi di tengah masyarakat merupakan proses penjurusan yang negatif dengan sendirinya akan mengkotak-kotaki wadah hidup bersama di daerah dalam bentuk kesatuan hidup terkecil berupa keluarga, daerahdaerah asal dan golongan agama. Garis kekerabatan yang cukup kuat mengikat selama ini dalam berbagai kasus menunjukkan kelonggarannya. Proses ini selanjutnya baik vertikal maupun horizontal saling mempengaruhi teknisadministrasi dan organisasi politik kelengkapan pemerintah daerah. Artinya bukan hanya pengkotakan pada masyarakat lapisan bawah tetapi pada tingkat elit dan birokrasi pemerintahan ada kecenderungan demikian (Arsip Muhammad Saleh Lahade Reg. 441 tentang pandangan atas Situasi di Daerah Sulawesi Selatan tanggal 1 Oktober 1968, n.d.).

Pada tahun 1950-an, terjadi musim paceklik di Sulawesi Selatan, termasuk wilayah Malili. Keadaan diperparah dengan gerakan DI/TII Kahar Muzakkar di wilayah pedalaman Luwu, sehingga mendorong terjadinya urbanisasi besarbesaran dari pedalaman Sulawesi Selatan ke Kota Makassar. Keamanan di pedesaan tidak menjamin adanya perubahan taraf kehidupan masyarakat ke arah yang lebih baik. Dias Pradadimara menjelaskan bahwa:

"terdapat dua gelombang migrasi masuk ke Kota Makassar dari tahun 1945 hingga tahun 1970. Gelombang migran pertama masuk ke kota di antara tahun 1945 hingga 1950 dari pelbagai daerah di Indonesia Timur sedangkan gelombang migran kedua masuk ke kota dari tahun 1950 hingga akhir tahun 1960-an dan mereka umumnya berasal dari daerah di Sulawesi Selatan sendiri. Arus masuk migran gelombang pertama lebih merupakan refleksi pentingnya posisi sosial politik Kota Makassar di daerah Indonesia bagian timur. Sedang para migran gelombang kedua masuk ke kota untuk menghindari ketidakamanan dan ketidakpastian di daerah pedesaan Sulawesi Selatan bersamaan dengan meluasnya operasi militer baik oleh TNI maupun oleh 'gerombolan.' Migran gelombang kedua ini berjumlah lebih banyak dari migran gelombang pertama" (Pradadimara, 2004: 8).

Situasi yang demikian tentunya tidak mendukung terbentuknya sebuah kabupaten di Luwu Utara. Oleh karena itu pada periode 1950an sampai 1960an dapat dikatakan sebuah periode kegagalan bagi bekas Kewedanan Masamba mengambil hak insititusinya sebagai pemerintahan Tingkat II sebagaimana di atur dalam Undang-Undang Pemerintahan Daerah Nomor 29 Tahun 1959.

Harapan kembali berkembang, ketika dikeluarkan Resolusi Dewan Perwakilan Rakyat Daerah Gotong Royong (DPRD GR) Daerah tingkat II Luwu di Palopo, Nomor 7/Res/DPRD-GR/1963 tanggal 2 Mei 1963, yang menyetujui eks Onder Afdeling Masamba menjadi Kabupaten. Kemudian, sebagai perkembangannya, dikeluarkanlah Resolusi Nomor 9/Res/DPRD-GR/1963 yang memutuskan untuk meninjau kembali Resolusi Nomor 7/Res/DPRD-GR/1963 tersebut, sehingga terdapat konsiderans yang berbunyi sebagai berikut: “......mendesak Pemerintah Pusat RI Cq. Departemen Pemerintahan Umum dan Otonomi Daerah agar membagi Dati II Luwu menjadi 4 Dati II yang baru terdiri dari Dati II Palopo, Dati II Tanah Manai, Dati II Masamba dan Dati II Malili”.

Berdasarkan laporan DPRD Provinsi Sulawesi Selatan pada sidang seksi Pemerintahan V tanggal 2 Mei 1966, dihasilkan kesimpulan sepakat untuk menyetujui tuntutan masyarakat eks 
Kewedanan Masamba menjadi Daerah Tingkat II dengan nama Kabupaten Masamba dengan ibukota di Masamba. Dilanjutkan pada Paripurna VI DPRD Provinsi Sul-Sel tanggal 9 Mei 1966 disetujui Eks Kewedanaan Masamba menjadi kabupaten. Lahirnya keputusan tersebut tidak dapat dilepaskan dari peran kalangan mahasiswa yang berasal dari wilayah Eks Kewedanaan Masamba, dimana secara bersama-sama kalangan muda tersebut dengan penuh semangat mendesak DPRD Provinsi Sulawesi Selatan untuk merekomendasikan pembentukan Kabupaten di Wilayah Eks Kewedanaan Masamba.

Pada tanggal 8 Oktober 1966 Panitia Persiapan Pembentukan Daerah Tingkat II Malili dan Masamba menghadap Sekjen Depdagri pada waktu itu (Soemarman, SH). Pada pertemuan itu, Sekjen berjanji akan mengirimkan Tim ke Daerah yang bersangkutan. Akan tetapi, pada masa Orde Baru perjuangan pembentukan Kabupaten Luwu Utara belum berhasil karena iklim politik pemerintahan Orde Baru yang cenderung sentralistik dan kontrol pusat terhadap daerah sangat kuat sehingga gerakan-gerakan pembentukan kabupaten atau pemekaran wilayah hampir tidak terdengar pada masa Orde Baru.

\section{Periode 1999 - pemekaran Luwu}

Tuntutan reformasi di segala bidang yang dilakukan oleh mahasiswa pada pertengahan 1997 pada akhirnya membawa Indonesia masuk ke era baru yaitu era reformasi. Lengsernya Soeharto sebagai Presiden Republik Indonesia pada $21 \mathrm{Mei}$ 1998 sebagai penanda runtuhnya era orde baru. Tampuk kepemimpinan kemudian diserahkan ke pundak BJ Habibie yang saat itu menjabat sebagai wakil presiden Republik Indonesia. Pada masa itu, mulai muncul gagasan-gagasan tentang desentralisasi dan pentingnya reformasi pemerintahan.

Gagasan-gagasan tersebut kemudian sangat membantu Luwu Utara untuk kembali menyampaikan keinginannya untuk membentuk sebuah kabupaten sendiri berpisah dari Luwu (induk). Apalagi sejak disahkannya UndangUndang Nomor 22 tahun 1999 yang memberi hak dan kewenangan kepada Pemerintah Daerah untuk mengelola Daerahnya sendiri diatas prakarsa, inisiatif masyarakat berdasarkan potensi daerahnya. Undang-undang tersebut secara sah menggantikan Undang-Undang Nomor 5 Tahun 1974 tentang Pemerintahan di Daerah yang Sentralistik.

Undang-Undang No 22 Tahun 1999 yang telah disusun oleh tim reformasi politik sejak sebelum jatuhnya Presiden Soeharto menjadi jalan tol bagi pemekaran-pemekaran yang terjadi di Indonesia pasca lengsernya Presiden Soeharto. Pada pasal 6 ayat 2 menyatakan bahwa daerah dapat dimekarkan menjadi dua landasan bagi daerah-daerah yang berkeinginan kuat memekarkan diri sejak awal (Muqoyyidin, 2013: 288-290).

Akibatnya, pada era reformasi ini, terdapat sejumlah pemekaran yang terjadi di Indonesia. Pembentukan Luwu Utara pada 1999 pun merupakan reaksi atas keinginan masyarakat Luwu Utara yang telah lama dan kemudian didukung oleh Undang-Undang Nomor 22/1999. Terlepas bahwa ada lobi-lobi khusus dari jaringanjaringan elit yang mempermulus jalan terbentuknya Luwu Utara. Ada aktor-aktor yang memiliki kepentingan atas pembentukan Luwu Utara.

Ryass Rasyid yang kebetulan memiliki kedekatan dengan Lutfi (caretaker Luwu Utara kemudian) melihat maraknya tuntutan pemekaran kabupaten di Provinsi Riau, Provinsi Lampung, Maluku Utara, Banten dan Bangka Belitung mengalir masuk ke tempatnya sebagai sebuah kesempatan bagi Luwu Utara. Saat itu Ryass menjabat sebagai Dirjen PUOD (Pemerintahan Umum dan Otonomi Daerah). Bahkan saat itu, dia terus menerima delegasi-delegasi daerah yang ingin memekarkan diri tersebut.

Kesempatan pembentukan Luwu Utara ini juga merupakan momentum bagi 
Lutfi A. Mutty yang kalah pada pemilihan Bupati Kepala Daerah di Luwu pada 1999. Ryass Rasyid meyakini bahwa pembentukan Luwu Utara ini merupakan kesempatan bagi Lutfi A. Mutty untuk menjadi kepala daerah setelah kekalahannya pada pemilihan kepala daerah di Luwu beberapa waktu sebelumnya. Hatta Pasajo pernah mendengar Lutfi berkata "Luwu Utara tidak akan terbentuk kalau bukan karena saya" (Pasajo, wawancara, Februari 2018). Ini adalah pernyataan Lutfi untuk meyakinkan bahwa Luwu Utara dibentuk salah satunya karena Ryass ingin Lutfi mengambil bagian di dalamnya. Jika boleh meminjam istilah orang lokal bahwa "Lutfi diberi kabupaten sendiri dan didrop disana".

Gerakan-gerakan pemekaran yang marak di Indonesia pasca terbitnya UU no 22/1999 disikapi oleh Ryass Rasyid dengan mengusulkan kepada Gubernur Sulawesi Selatan HZB Palaguna untuk menyetujui pemekaran Luwu sebagai antisipasi sebelum gerakan serupa terjadi (Muis, 2008: xxvii). Ide Ryass yang disampaikan kepada Gubernur Sulawesi Selatan akhirnya diteruskan kepada Dick Darnadi. Gubernur menghimbau kepada Dick untuk membantu perjuangan pembentukan Masamba sebagai kabupaten. Saat itu Dick menjabat sebagai Kepala Direktorat Sosial Politik (kaditsospol) Provinsi Sulawesi Selatan yang memiliki kekuasaan yang cukup besar. Ditambah dia juga memiliki kedekatan dengan Gubernur Sulawesi Selatan sehingga informasi pemekaran Luwu disampaikan kepadanya. Dick Darnadi adalah orang Solo yang menikah dengan orang Masamba. Pernikahan tersebut membuat dia menjadi bagian dari Masamba sehingga keinginan Masamba memekarkan diri dari Luwu turut pula dia rasakan.

Dick Darnadi lalu menindaklanjuti dengan meminta bantuan kepada tokohtokoh masyarakat termasuk kepada mahasiswa di Masamba untuk membantu menyiapkan berkas administrasi yang dibutuhkan demi terbentuknya Kabupaten Luwu Utara. Saat itu juga langsung ditanggapi secara cepat oleh Camat Masamba, Arifin Junaedi dan beberapa orang tokoh lainnya seperti $\mathrm{H}$. Hatta Idar (pengusaha), H. Tahir, Usman Lussa (Alm). Sebagai langkah awal Camat Masamba mengambil langkah untuk melakukan penertiban dan pembersihan kota. Hal ini dilakukan untuk menjaga jika ada tim dari pusat akan meninjau kondisi layak tidaknya Kota Masamba dimekarkan (Darnadi, wawancara, Februari 2018).

Masih kuat di ingatan H. Hatta Idar ketika dia dan kawan-kawannya harus ke Bone-Bone, Sukamaju dan daerah-daerah lainnya untuk mendapatkan dukungan masyarakat. Mereka harus rela mengetuk setiap pintu rumah untuk mendapatkan tanda tangan pernyataan setuju Masamba memisahkan diri dari Luwu. Begitupun seterusnya begitu ada informasi dari Dick Darnadi tentang kebutuhan-kebutuhan administrasi terkait pemekaran. Mereka akan segera menggelar rapat di rumah Usman Lussa. Gerakan yang mereka lakukan tanpa dibiayai oleh pihak manapun. Semua gerakan yang dilakukan murni dengan merogoh kantong sendiri. Keinginan mereka sebagai masyarakat Masamba yang ingin melihat Masamba membentuk kabupatennya sendiri begitu kuat (Idar, Tahir, Junaedi, Mammala, wawancara, Maret 2018).

Selain tokoh-tokoh yang disebutkan ini, tentu masih banyak tokoh lain yang turut berperan penting dalam persiapan pembentukan Luwu Utara. Sebab tanpa usulan dari bawah tentu tak mungkin Ryass Rasyid maupun Lutfi yang bergerak di pusat (Jakarta) mampu menggolkan pembentukan Kabupaten Luwu Utara. Tokoh-tokoh inilah kemudian yang membantu menyiapkan berkas-berkas lain yang dibutuhkan oleh Lutfi A. Mutty dan Ryass Rasyid dalam mempermulus pembentukan Luwu Utara.

Ryass Rasyid juga menyampaikan usulannya ini ketika memberi ceramah di Universitas Hasanuddin. Usulannya akan 
hanya tinggal usulan jika tidak ada usulan dari bawah. Dan dengan caranya sendiri Ryass mencoba untuk memancing semangat otonomi daerah dan pemekaran kepada mahasiswa Universitas Hasanuddin. Mahasiswa terpancing, di antaranya dari Luwu. Ryass menantang bahwa jika ingin membuat satu kabupaten pemekaran harus ada usulan dari bawah (Muis, 2008: 86).

Menurut pengakuan Kadri Tasran yang saat itu berstatus mahasiswa yang berasal dari Masamba bahwa pada masa perjuangan pemekaran Kabupaten Luwu Utara, mahasiswa juga turut memberikan dorongan dengan pernyataan sikap mendukung sepenuhnya pemekaran di Tanah Luwu. Mahasiswa lalu membentuk Forum Komunikasi Mahasiswa Luwu Utara, dan pertemuan dalam rangka membicarakan upaya pemekaran dilaksanakan di rumah bapak Usman Lussa.

Pro dan kontra pembentukan Kabupaten Luwu Utara terjadi di berbagai lini. Termasuk di dalam tubuh mahasiswa yang tergabung dalam IPMIL. IPMIL yang saat itu diketuai oleh Hamka Hidayat menolak pemekaran Luwu Utara, dan sebagian anggotanya tidak sepakat dengan pandangan itu terutama IPMIL cabang Masamba. IPMIL Komisariat Masamba diwakili oleh Kadri Tasran bersama dengan beberapa orang bertemu dengan Camat Masamba bapak Arifin Junaidi lalu sepakat untuk membentuk forum tersendiri yang dinamakan Forum Komunikasi Mahasiswa Luwu Utara (FKPMLU) (Kadri dan Djunaedi, wawancara, Maret 2018).

Setelah terbentuk forum, langkah selanjutnya mendatangi perwakilanperwakilan mahasiswa setiap kecamatan dan kemudian dibuat konsep pernyataan dukungan pemekaran. Pernyataan sikap dengan nomor surat 1st/B/SEK/FKPMLU/II/1999 tertanggal 23 Februari 1999 tersebut ditujukan kepada Ketua DPR/MPR RI, Presiden Republik Indonesia, Menhankan Pangab RI, Komnas HAM RI, Ketua DPRD Tk. I Sulsel,
Gubernur KDH Tk. I Sulsel, Pangdam VII Wirabuana, DPRD Tk. II Luwu, Bupati KDH Tk. II Luwu dan pers. Isi pernyataan sikap tersebut adalah mendukung pemekaran wilayah Luwu. Surat ini ditandatangani oleh ketua-ketua komisariat kecamatan dari 13 kecamatan. Kecamatan tersebut adalah Kecamatan Wotu, Masamba, Nuha, Sabbang, Sukamaju, Walenrang, Malili, Mappadeceng, Malangke, Burau, Bone-bone, Mangkutana, dan Baebunta.

Setelah 3 (tiga) hari berlalu, kemudian perwakilan FKPMLU menuju ke kantor DPRD Provinsi Sulawesi Selatan, dan di kantor DPRD mereka menemui bentangan spanduk dari pihak yang menolak pemekaran yang bertuliskan "haram hukumnya pemekaran Luwu Utara" (Tasran, wawancara, 2 Maret 2018). Forum lalu mengutus 2 (dua) perwakilan mahasiswa yaitu Kadri Tasran bersama dengan saudara Jumal Lussa yang mewakili atas nama FKPMLU untuk ke DPRD Provinsi secara sembunyi-sembunyi tanpa diketahui oleh pengurus IPMIL.

Saat itu pertemuan dilaksanakan di DPRD Provinsi Sulawesi Selatan, ada beberapa tokoh masyarakat yang hadir antaralain Sabani, Andi Hasan (Ketua DPRD Luwu), beserta tokoh-tokoh lainnya dan saat itu dibacakan pernyataan sikap pemekaran di DPRD Provinsi. Setelah itu, giliran mahasiswa yang diwakili oleh Kadri Tasran dan Jumal Lussa yang membacakan pernyataan mahasiswa terkait dukungan pemekaran dibacakan oleh Kadri Tasran selaku perwakilan forum. Pelajar/mahasiswa yang pro terhadap pembentukan Luwu Utara sempat mendapat ancaman dari kepengurusan IPMIL terkait gerakan-gerakan yang mereka lakukan (Tasran, wawancara, 2 Maret 2018).

Pasca dari kantor DPRD Provinsi, perwakilan mahasiswa Luwu Utara ini diajak ke jalan Nuri, Makassar oleh bapak Andi Hasan, membahas tentang utusan yang akan berangkat ke Jakarta untuk membawa dokumen aspirasi pemekaran. 
Andi Hasan ketika itu menjabat sebagai ketua DPRD Luwu sehingga dia memiliki andil yang sangat besar terhadap proses pemekaran. Pada saat dia menyampaikan hasil LDP bahwa pemekaran dapat dilakukan dengan catatan bahwa ibukota nantinya akan ditempatkan di Tarengge. Menyikapi hal tersebut mahasiswa tetap mempertahankan Masamba sebagai ibukota dan bertahan untuk tidak menandatangani dokumen tersebut.

Perwakilan mahasiswa yang berangkat ke Jakarta yakni Nirwan Hasan. Saat di Jakarta, pernyataan dari mahasiswa dibacakan oleh Supri Balanca bahwa yang menolak pemekaran bukan dari Masamba walaupun ada sebagian yang terlibat. Forum mahasiswa yang telah dibentuk tersebut yang kemudian menjadi organda Pemilar melalui deklarasi pembentukan organda sebagai wadah berhimpun mahasiswa dari Luwu Utara.

Sebagaimana pemekaran di berbagai wilayah, tidak dapat dipungkiri bahwa akan ada pihak yang kontra terhadap pemekaran dengan berbagai alasan di pandang dari sudut pandang tertentu dan tentunya karena juga sarat dengan unsur kepentingan politis. Begitupun juga pada pemekaran Kabupaten Luwu. Proses pembentukan Luwu Utara yang cepat tidak sampai membuat pihak yang kontra dapat berbuat banyak. Walaupun demikian ada saja tindakan yang cukup membuat pihak pro pembentukan harus berfikir ekstra.

Tindakan pihak yang kontra tidak hanya dilakukan dengan cara demonstrasi dan pemasangan spanduk saja bahkan sampai pada mengupayakan tim DPR RI untuk tidak berkunjung ke Masamba. Tim DPR RI akan memantau kesiapan pemekaran Masamba. Pada saat di Palopo, Tim DPR RI didatangi oleh sekelompok masyarakat dan mereka menyampaikan bahwa tim tidak perlu ke Masamba karena Masamba tidak menginginkan pemekaran.

Pada saat itu, tim lokal pemekaran sudah mendengar berita bahwa ada sekelompok masyarakat yang menghalangi pemekaran Luwu Utara, sehingga Camat
Masamba yang saat itu dijabat oleh Arifin Junaedi mengirim utusan ke Palopo untuk melihat kondisi dan situasi sekaligus bertemu dengan tim dari DPR RI tersebut. Selain itu, diantara tim itu juga ada dua orang teman Dick Darnadi dari ABRI yang ikut, sehingga isu yang dihembuskan oleh kelompok yang kontra dapat ditepis (Djunaedi, wawancara, 5 Maret 2018).

Setelah tiba di Palopo, tim lokal menyampaikan kepada tim DPR RI bahwa masyarakat Luwu Utara sangat siap untuk pemekaran kabupaten sehingga tim akhirnya turun mengunjungi Masamba. Pada saat berada di Masamba Tim DPR RI diterima dan dijamu di rumah jabatan Camat pada waktu itu. Melalui perbincangan dan diskusi panjang yang digelar di rumah jabatan dan juga di rumah adat, disampaikan kepada ketua tim DPR RI, bahwa pada prinsipnya masyarakat Masamba sangat menginginkan pemekaran dengan harapan bahwa Luwu Utara harus mekar dengan Masamba sebagai ibu kota.

Mendahului kedatangan tim DPR RI, tim lokal yang diketuai oleh Arifin Djunaedi menggelar pertemuan di rumah bapak Usman Lussa terkait kesiapan pemekaran termasuk persiapan lokasi perkantoran. Dalam rombongan DPR RI termasuk ada di antaranya orang Luwu yakni bapak Fahri Leluasa sebagai tim peninjau persiapan pemekaran dan beliau menyarankan tentang perlunya lokasi untuk persiapan perkantoran.

Jatuh bangunnya tim-tim di daerah (Masamba) membuktikan bahwa ada banyak unsur penting di daerah yang terlibat dalam pembentukan Luwu Utara tak terkecuali dari unsur mahasiswa. Keterlibatan tersebut jelas diakui dan termaktub didalam penjelasan UndangUndang Republik Indonesia Nomor 13 Tahun 1999 tentang pembentukan Kabupaten Daerah Tingkat II Luwu Utara. Di bagian umum, tertera sebagai berikut: [...] dengan memperhatikan aspirasi yang berkembang dalam masyarakat sebagaimana yang tertuang dalam Keputusan Dewan Perwakilan 
Rakyat Daerah Tingkat II Luwu tanggal 10 Februari 1999 Nomor 03/KPTS/DPRD/II/1999 tentang usul dan persetujuan pemekaran wilayah Kabupaten Daerah Tingkat II Luwu menjadi dua kabupaten [...]

Semangat dan keinginan masyarakat di eks. Onder Afdeling Masamba dan Malili untuk kembali menghidupkan tuntutan pembagian Kabupaten Luwu menjadi 4 (empat) Dati II yang telah mendapat persetujuan DPRD Kab. Luwu melalui SK DPRD Kab. Luwu No.03/KPTS/DPRD/III/1999 pada tanggal 10 Februari 1999.

Hal ini tercermin melalui penyampaian aspirasi Tokoh Masyarakat, Pemuda, para sesepuh pada temu konsultasi pansus DPRD Provinsi Sulawesi Selatan tanggal 26 s/d 27 Februari 1999 di Belopa, Palopo, Masamba dan Malili, dan temu konsultasi Pansus DPRD Provinsi Sulawesi Selatan dengan tokoh masyarakat Luwu yang berdomisili di Makassar serta laporan kondisi obyektif rencana pemekaran Kab. Dati II Luwu tanggal 5 Maret 1999.

Hal tersebut kemudian menjadi dasar DPRD Provinsi Sulawesi Selatan untuk menerbitkan Keputusan DPRD Sulsel No.21/III/1999 tentang pemberian persetujuan terhadap Rencana Pemekaran Kabupaten Dati II Luwu menjadi 2 (dua) Dati II pada tanggal 6 Maret 1999 untuk tahap I (pertama) dan selanjutnya dapat dimekarkan lagi sesuai perkembangan kebutuhan dan potensi daerah serta meningkatkan status Kotif Palopo menjadi Kotamadya Dati II.

Akhirnya setelah melalui proses yang cukup panjang dari tahun 1959 sampai dengan tahun 1999, Kabupaten Dati II Luwu resmi dibagi menjadi 2 (dua) Kabupaten Dati II yaitu Kabupaten Dati II Luwu dan Kabupaten Dati II Luwu Utara. Sehingga berdasarkan Undang-Undang Nomor 13 Tahun 1999 tertanggal 27 April 1999 terbentuklah Kabupaten Dati II Luwu Utara dengan ibukotanya Masamba.

\section{PENUTUP}

Gagasan pembentukan Kabupaten Luwu Utara bukanlah gagasan yang hanya sekali ini muncul, tapi keinginan tersebut sudah sejak lama diperjuangan. Gagasan pertama mulai merebak dan diperjuangkan secara bersungguh-sungguh pada 1959. Sebagai dasar utamanya, secara sangat jelas termaktub dalam Undang-undang Nomor 29 Tahun 1959 tentang Pembentukan Daerah Tingkat II di Sulawesi Selatan (L.N. 1959 Nomor 74 TLN Nomor 1822) yang mengamanatkan bahwa semua daerah eks Onder-Afdeling di Sulawesi Selatan, termasuk di antaranya bekas Kewedanan Masamba akan ditingkatkan statusnya menjadi kabupaten. Akan tetapi, usaha pembentukan Kabupaten Luwu Utara gagal karena situasi keamanan Sulawesi Selatan, terutama adanya Gerakan DI/TII Kahar Muzakkar, di mana ruang lingkup gerakan ini juga meliputi wilayah Kewedanaan Masamba. Pada periode ini situasi ketentraman dan keamanan pada hampir seluruh kawasan ini, sangat mencekam dan memprihatinkan akibat aksi para gerombolan pemberontak yang membumihanguskan banyak tempat, termasuk Kota Masamba. Peristiwa ini, secara langsung melahirkan semangat heroisme yang membara, khususnya di kalangan para pemuda pada waktu itu, untuk berjuang keras dengan tujuan membangun kembali wilayah eks Kewedanan Masamba yang porak poranda. Upaya pembentukan Dati II Kabupaten Masamba kembali diperjuangkan pada 1966. Akan tetapi, pada masa Orde Baru perjuangan pembentukan Kabupaten Luwu Utara belum berhasil karena iklim politik pemerintahan Orde Baru yang cenderung sentralistik dan kontrol pusat terhadap daerah sangat kuat sehingga gerakangerakan pembentukan kabupaten atau pemekaran wilayah hampir tidak terdengar pada masa Orde Baru.

Pada 1999, upaya pembentukan Kabupaten Luwu Utara yang digagas oleh masyarakat Luwu Utara akhirnya berhasil. 
Upaya pembentukan Luwu Utara tidak lagi membutuhkan waktu lama. Tidak dapat dipungkiri, cepatnya proses pembentukan Luwu Utara pada 1999 ini berkat politik lobbying dimana ada peran Ryass Rasyid (Dirjen PUOD) di Jakarta yang memiliki kedekatan khusus dengan Lutfi A. Mutty. Kedekatan ini membawa berkah terhadap Lutfi A. Mutty yang kemudian ditetapkan sebagai caretaker di Luwu Utara.

Perjuangan pembentukan Luwu Utara adalah bukan usaha orang per orang, namun adalah berkat perjuangan masyarakat Luwu Utara yang terdiri dari berbagai unsur, unsur mahasiswa yang tergabung pada Forum Komunikasi Mahasiswa Luwu Utara, unsur masyarakat biasa (H. Hatta Idar, Usman Lussa, H. Tahir, Mustika Dg. Mamala) bahkan unsur pemerintah yang diwakili oleh Andi Hasan selaku ketua DPRD Luwu juga Arifin Junaedi (Camat Masamba). Selain itu di tingkat provinsi yaitu Gubernur Sulawesi Selatan dan Dick Darnadi selaku Kepala Direktorat Sosial Politik (kadits sospol) Provinsi Sulawesi Selatan juga memiliki andil cukup besar terhadap pembentukan Luwu Utara.

Pembentukan Luwu Utara dilakukan karena beberapa faktor, antara lain: luas wilayah yang dimiliki oleh Luwu menyebabkan banyak daerah-daerah yang terabaikan. Jadi, pembentukan Luwu Utara dilakukan bukan saja dilandasi oleh semangat emosional atas eforia reformasi, akan tetapi juga dilandasi oleh kebutuhan masyarakat akan pelayanan pemerintahan yang cepat dan prima serta landasan logika pemerintahan yaitu sulitnya rentang kendali pemerintahan yang disebabkan oleh terlalu luasnya wilayah administratif pemerintahan, dan kondisi ini akan berimbas pada lambat dan mahalnya pelayanan publik yang diberikan kepada masyarakat, utamanya masyarakat yang jauh dari ibukota pemerintahan. Hal ini pulalah yang kemudian diuraikan dalam Undang-Undang Republik Indonesia Nomor 13 Tahun 1999 tentang Pembentukan Kabupaten Daerah Tingkat
II Luwu Utara, dimana diuraikan pembentukan Luwu Utara karena menimbang 4 hal.

Alasan lain yang tidak dapat diabaikan bahwa perjuangan pemekaran wilayah di Luwu menyimpan sejumlah pertanyaan besar dan sebuah agenda tersembunyi untuk pembentukan Provinsi Luwu Raya yang ketika itu sedang marak diperbincangkan di tingkat nasional. Agenda-agenda ini juga menjadi jalan yang mempermulus pembentukan Luwu Utara disamping peran berbagai aktor di dalamnya. Semua faktor tidak dapat diabaikan dalam proses terbentuknya Luwu Utara.

Alasan dibalik terbentuknya Kabupaten Luwu Utara tidak hanya dikarenakan pertimbangan desentralisasi, demokratisasi dan good governance, serta kalkulasi ekonomis namun juga karena kepentingan aktor-aktor dibaliknya. Namun secara keseluruhan pembentukan Luwu adalah tuntutan aspirasi masyarakat Masamba sejak tahun 1959 yang baru bisa diwujudkan pada 1999.

\section{UCAPAN TERIMA KASIH}

Terima kasih terkhusus kepada pak Ulla (Masamba) yang telah banyak membantu dan menuntun penulis kepada informan yang terhubung dengan peristiwa pembentukan Kabupaten Luwu Utara. Juga, terima kasih kepada seluruh informan atas segala data dan dokumen yang dibagikan secara sukarela kepada penulis untuk diakses dan dirakit menjadi sebuah tulisan.

\section{DAFTAR SUMBER}

Agung, M. (2016). Pengaruh Pemekaran terhadap Kualitas Pelayanan Publik di Kecamatan Buntu Batu Kabupaten Enrekang. Universitas Hasanuddin.

Amin, B., Hasanuddin, \& Tilome, R. (2013). Mengukuhkan Jati Diri. Dinamika Pembentukan Provinsi Gorontalo (1999 - 2001). Yogyakarta: Ombak.

Arghiros, D. (2001). Democracy, Development and Decentralisation in Provincial 
Thailand. Surrey: Surzon.

Arsip Muhammad Saleh Lahade Reg. 441 tentang pandangan atas Situasi di Daerah Sulawesi Selatan tanggal 1 Oktober 1968. (n.d.)

Darnadi, D. (Februari 2018). Wawancara.

Djunaedi, A. (Maret 2018). Wawancara.

Erman, E. (2012). Remembering and forgetting: The History of Sheikh Yusuf Struggle for Human Rights. Heritage of Nusantara: International Journal of Religious Literature and Heritage, 1(1), 101-122.

Harvey, B. S. (1983). Permesta: Pemberontakan Setengah Hati. Jakarta: Grafiti Press.

Hughes, S. (1964). History as Art and as Science. New York.

Idar, H., Tahir, Junaedi, A., Mammala, M. D. (Maret 2018). Focus Group Discussion.

Kementerian Penerangan. (1952). Provinsi Sulawesi Selatan. Jakarta: Kementerian Penerangan.

Lloyd, C. (1993). The Structures of History. Blackwell: Oxford.

Mattulada, M. T. (2017). Dinamika Politik Pembentukan Provinsi Sulawesi Barat. Makassar: Pustaka Sawerigading bekerjasama dengan Balai Pelestarian Nilai Budaya Sulawesi Selatan.

Muis, A. (2008). Lutfi A. Mutty: Pioneer Luwu Utara. Yogyakarta: Citra Pustaka.

Muqoyyidin, A. W. (2013). Pemekaran Wilayah dan Otonomi Daerah Pasca Reformasi di Indonesia: Konsep, Fakta Empiris dan Rekomendasi ke Depan. Jurnal Konstitusi, 10(2), 287-309.

Nordholt, H. S. \& Klinken, G. v. (2007). Politik Lokal di Indonesia. Jakarta: KILTV dan Yayasan Obor Indonesia.

Pasajo, H. (26 Februari 2018). Wawancara.

Pradadimara, D. (2004). Penduduk Kota, Warga Kota, dan Sejarah Kota: Kisah Makassar, Draf Pertama, Juli 2004. Surabaya.
Rohmah, N. S. (2018). Elit dan Pemekaran Daerah; Konflik Antar Elit dalam Proses Pembentukan Provinsi Banten. Cosmogov: Jurnal Ilmu Pemerintahan, 4(1), 90-105.

Sulistyo, H. (2000). Palu Arit di Ladang Tebu: Sejarah Pembantaian Massal yang terlupakan. Jakarta: Gramedia.

Tasran, K. (02 Maret 2018). Wawancara

Trisnawati, A. (2015). Analisis Peran Aktor dalam Pemekaran Kabupaten Brebes. Journal of Politic and Government Studies, 4(2), 1-21.

Yosephus, S. (2014). Dampak Pemekaran Wilayah Terhadap Pelayanan Publik (Suatu Studi Di Kantor Kecamatan Tombariri Timur Dalam Pelayanan Administrasi Pengurusan Kartu Keluarga). Jurnal Politico, 3(19). 